\title{
Correlation between dynamic and static modulus of elasticity in mini panels of soil-cement
}

\author{
Wélida S. Sarro (IC), Gisleiva C. S. Ferreira (PQ)
}

\begin{abstract}
The application of nondestructive testing in buildings with soil aims to conduct inspections and technological control with minimal interventions. To achieve the objectives proposed study mini panels in proportions of 1 : 8, 1:12, 1:16 (Portland cement: soil). The ultrasound test enabled to correlate the elastic properties of the mini panels. It was possible to detect the excellent correlations between the modulus of elasticity of the differences recipes.
\end{abstract}

Key words: rammed earth, nondestructive testing, ultrasonic pulse

\section{Introduction}

Among the non-destructive tests set out to analyze the state of disrepair of the buildings is the ultrasound test ${ }^{12}$, which allows to obtain the elastic constants of the material (longitudinal and shear modulus and Poisson's ratio) required values in the structural design. Therefore, the aim of this study was to correlate the dynamic modulus of elasticity obtained by ultrasound testing and static modulus of elasticity obtained through axial compression of the soil-cement mini panels.

\section{Results and Discussion}

The static and dynamic modulus of elasticity were obtained from the results of the ultrasonic test (Figure 1) and the compression test (Figure 2), respectively.

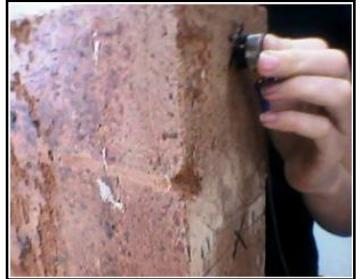

Figure 1. Ultrasonic Test.

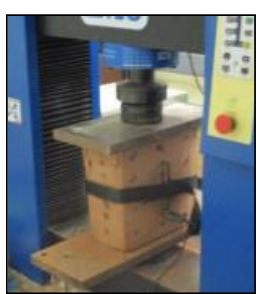

Figure 2. Compression Test.
Table 1. Average values of modulus of elasticity

\begin{tabular}{ccc}
\hline Recipe & $\begin{array}{c}\text { Ed } \\
\text { (MPa) }\end{array}$ & $\begin{array}{c}\mathbf{E} \\
\text { (MPa) }\end{array}$ \\
\hline T & - & 1135 \\
A & 7280 & 7018 \\
B & 6008 & 5300 \\
C & 3209 & 3227 \\
\hline
\end{tabular}

The data of dynamic and static elastic modulus obtained a correlation $R=0.94$ with $p$-value $\leq$
0.05 , according to statistical analysis performed by Statgraphics Centurion XVII software.

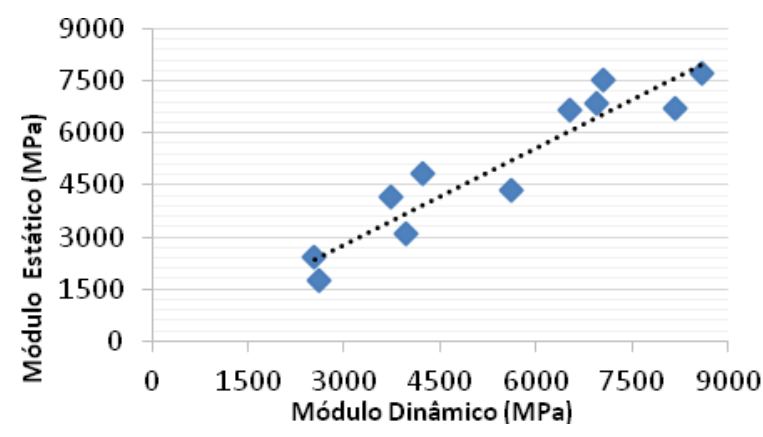

Conclusions

The ultrasound test allowed correlate the elastic properties in the mini-panels. Moreover, it was possible to detect differences in mechanical behavior of the different features of the miniboards, whereas the mixtures with higher cement content and improved compressed showed greater speed of ultrasonic pulse. The analysis also indicates the possibility of applying the ultrasound technique during the technological control of buildings on the ground.

\section{Acknowledgement}

SAE - UNICAMP; LabEND - Feagri and College of Technology - UNICAMP.

${ }^{1}$ HOFFMANN, V. M. e GONÇALVES, R. "Análise da qualidade da taipa de pilão por meio de ondas ultrassônicas". In: III Congresso de Arquitetura e Construção com Terra no Brasil. CD, Anais, Campo Grande, UFMS, 2010.

${ }^{3}$ MICCOLI, L., MÜLLER, U., FONTANA, P., "Mechanical behaviour of earthen materials: A comparison between earth block masonry, rammed earth and cob". Construction and Building Materials 61. Editora Elsevier, Germania, 2014. 